\title{
Pengaruh Kepemilikan Manajerial, Kepemilikan Institusional, dan Pengungkapan CSR Pada Kinerja Keuangan Perusahaan
}

\author{
Luh Gede Dian Hermayanti ${ }^{1}$ \\ I Made Sukartha ${ }^{2}$ \\ ${ }^{1,2}$ Fakultas Ekonomi dan Bisnis Universitas Udayana (Unud), Bali, Indonesia \\ e-mail: dianherma12@gmail.com
}

\begin{abstract}
ABSTRAK
Tujuan penelitian ini untuk membuktikan secara empiris pengaruh kepemilikan manajerial, kepemilikan institusional, dan pengungkapan corporate social responsibility pada kinerja keuangan perusahaan pertambangan yang terdaftar di Bursa Efek Indonesia periode 20122016. Teknik analisis data yang digunakan adalah analisis regresi linier berganda. Hasil penelitian menunjukkan bahwa hipotesis pertama dan ketiga dalam penelitian ditolak, yaitu kepemilikan manajerial dan pengungkapan CSR tidak berpengaruh pada kinerja keuangan perusahaan pertambangan yang terdaftar di Bursa Efek Indonesia periode 2012-2016. Hipotesis kedua dalam penelitian ini diterima, yaitu kepemilikan institusional berpengaruh positif pada kinerja keuangan perusahaan pertambangan yang terdaftar di Bursa Efek Indonesia periode 2012-2016.

Kata kunci: Kepemilikan institusional, kepemilikan manajerial, pengungkapan corporate social responsibility, kinerja keuangan
\end{abstract}

\begin{abstract}
The purpose of this study is to prove empirically the effect of managerial ownership, institutional ownership, and disclosure of corporate social responsibility on the financial performance of mining companies listed on the Indonesia Stock Exchange for the period 2012-2016.. The data analysis technique used is multiple linear regression analysis. The results showed that the first and third hypotheses in the study were rejected, namely managerial ownership and disclosure of CSR did not affect the financial performance of mining companies listed on the Indonesia Stock Exchange for the period 2012-2016. The second hypothesis in this study is accepted, namely institutional ownership has a positive effect on the financial performance of mining companies listed on the Indonesia Stock Exchange for the period 2012-2016.

Keywords: Institutional ownership, managerial ownership, disclosure of corporate social responsibility, financial performance
\end{abstract}

\section{PENDAHULUAN}

Kinerja keuangan perusahaan merupakan gambaran tentang kondisi keuangan suatu perusahaan, sehingga dapat diketahui mengenai baik buruknya keadaan keuangan suatu perusahaan yang mencerminkan prestasi kerja dalam periode tertentu. Kinerja keuangan perusahaan dapat dilihat dari laporan keuangan perusahaan, sehingga diketahui keadaan finansial dari hasil yang telah dicapai 
Luh Gede Dian Hermayanti dan I Made Sukartha. Pengaruh ...

perusahaan selama periode tertentu. Pengukuran kinerja keuangan dilakukan untuk mengetahui apakah hasil yang dicapai perusahaan sudah sesuai dengan yang direncanakan. Dengan meningkatnya kinerja keuangan perusahaan berarti bahwa perusahaan dapat mencapai tujuan dari didirikannya perusahaan tersebut.

Penilaian kinerja keuangan dilakukan melalui analisis rasio keuangan. Salah satu rasio keuangan yang digunakan untuk mengukur kinerja keuangan adalah rasio profitabilitas. Rasio profitabilitas adalah rasio atau perbandingan untuk mengetahui kemampuan perusahaan untuk mendapatkan laba dari pendapatan terkait dengan penjualan, aset, dan ekuitas berdasarkan pengukuran tertentu. Ada beberapa alat ukur yang digunakan untuk mengukur tingkat profitabilitas, yaitu Gross Profit Margin, Net Profit Margin, Return on Asset, Return on Equity, Return on Sales, Return on Capital Employed, Return on Investment, dan Earning Per Share. Pada penelitian ini tingkat profitabilitas akan diukur dengan menggunakan Return on Equity (ROE).

Berikut adalah laba setelah pajak perusahaan pertambangan yang terdaftar di Bursa Efek Indonesia tahun 2012-2016: 


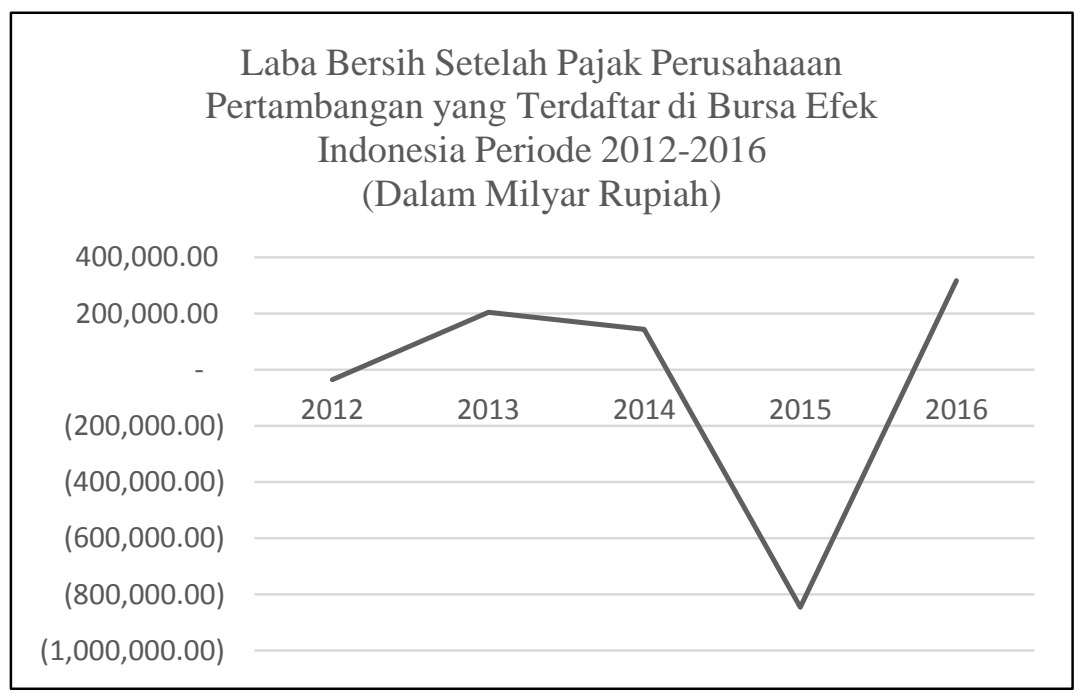

Sumber: Data diolah, 2018

Gambar 1. Laba Bersih Setelah Pajak

Berdasarkan grafik diatas, tingkat laba bersih perusahaan pertambangan yang terdaftar di Bursa efek Indonesia periode 2012-2016 mengalami fluktuasi. Pada tahun 2012-2015 laba bersih setelah pajak perusahaan pertambangan cenderung mengalami penurunan. Hal tersebut diakibatkan oleh penurunan harga komoditas pada beberapa sektor, terutama pada sektor batubara. Pada tahun berikutnya, harga komoditas cenderung semakin menurun akibat dari tahun sebelumnya. Pada tahun 2015 merupakan tahun yang penuh tantangan bagi perusahaan pertambangan, sebab terjadinya penurunan harga komoditas dibandingkan tahun sebelumnya. Perusahaan pertambangan harus berupaya untuk meningkatkan produktivitas, pengurangan biaya dan meminimalisir modal selama masa sulit ini. Namun, pada tahun 2016 terjadi kenaikan harga sejumlah komoditas yang disertai dengan perbaikan keyakinan investor pada perusahaan pertambangan. Laba yang rendah menunjukkan bahwa perusahaan tidak efektif dan efisien dalam melaksanakan aktivitas perusahaan. Tingkat laba bersih yang tinggi pada perusahaan akan meningkatkan daya saing antar perusahaan. Tingkat 
Luh Gede Dian Hermayanti dan I Made Sukartha. Pengaruh ...

keuntungan yang tinggi menandakan pertumbuhan perusahaan pada masa mendatang. Kelangsungan usaha (going concern) perusahaan merupakan keadaan dimana perusahaan dapat atau telah beroperasi dalam jangka waktu ke depan yang dipengaruhi oleh keadaan finansial dan non finansial. Dalam hal ini laba dinilai sangat penting karena untuk melangsungkan hidupnya suatu perusahaan haruslah berada dalam keadaan yang menguntungkan. Para direktur, pemilik perusahaan, dan yang paling utama adalah pihak manajemen perusahaan akan berusaha untuk meningkatkan keuntungan perusahaan, karena menyadari akan pentingnya laba bagi masa depan perusahaan. Salah satu yang dapat dilakukan oleh perusahaan adalah dengan menjaga kualitas kerja dalam perusahaan, terutama dalam hal peningkatan kinerja keuangan perusahaan.

Kinerja keuangan perusahaan dipengaruhi oleh mekanisme good corporate governance yang dibagi menjadi dua bagian yaitu eksternal dan internal (Karmilayani \& Damayanthi, 2016). Mekanisme internal dilakukan oleh dewan direksi, dewan komisaris, komite audit, serta kepemilikan manajerial, sedangkan mekanisme eksternal terdiri dari kepemilikan institusional. Corporate governance dapat dijelaskan dengan teori keagenan yaitu bahwa adanya pemisahan antara kepemilikan dan pengendali perusahaan. Corporate governance dilatarbelakangi oleh teori keagenan yang menyatakan bahwa permasalahan keagenan muncul saat kepengurusan suatu perusahaan terpisah dari pemiliknya. Manajemen (agen) merupakan pihak yang dikontrak oleh pemegang saham (principal) untuk bekerja demi kepentingan pemegang saham. Oleh sebab itu, manajemen mempunyai tanggung jawab atas semua tindakan yang dilakukan kepada pemegang saham. 
Hubungan antara agen dan principal haruslah ada simetri informasi. Artinya semua informasi mengenai perusahaan yang dimiliki agen seharusnya diungkapkan kepada principal. Agen sebagai pihak yang memiliki kualitas dan kuantitas informasi yang lebih baik dari pada principal akan memanfaatkan hal tersebut untuk memenuhi kepentingannya sendiri dengan melakukan tindakan yang dapat merugikan principal. Permasalahan yang timbul antara principal dan agen menimbulkan biaya keagenan. Solusi untuk mengurangi konflik tersebut adalah dengan menerapkan tata kelola perusahaan yang baik (Good Corporate Governance). Menurut Wahidahwati (2002), masalah yang ditimbulkan antara agen dan principal dapat dikurangi melalui beberapa alternatif berikut: 1) Meningkatkan kepemilikan saham perusahaan oleh manajemen (insider ownership). Dengan kepemilikan manajerial, manajemen akan ikut merasakan langsung dampak dari segala tindakan dan keputusan yang dilakukannya. 2) Peningkatan kepemilikan institusional (institusional investor) sebagai pihak yang memonitor agen. Dengan kepemilikan institusional maka distribusi saham akan menyebar yang nantinya akan mendorong peningkatan pengawasan agar lebih optimal terhadap kinerja manajemen, sehingga dapat mengurangi biaya keagenan. 3) Meningkatkan deviden payout ratio sehingga akan mengurangi free cash flow dan manajemen terpaksa mencari sumber pendanaan dari luar. 4) Meningkatkan penggunaan utang dalam pendanaan karena dapat menurunkan excess cash flow yang tersedia untuk manajer untuk melakukan tindakan-tindakan yang tidak semestinya menjadi terbatas. 
Luh Gede Dian Hermayanti dan I Made Sukartha. Pengaruh ...

Peningkatan kinerja keuangan pada perusahaan pertambangan dipengaruhi oleh beberapa variabel, dalam penelitian ini peneliti memilih variabel kepemilikan manajerial dan kepemilikan institusional. Peraturan Otoritas Jasa Keuangan Nomor 11/POJK.04/2017 tentang laporan kepemilikan atau setiap perubahan kepemilikan saham perusahaan terbuka. Perusahaan publik wajib mengungkapkan jumlah lembar saham dan persentase kepemilikan, yaitu: 1) Pemegang saham yang memiliki $5 \%$ atau lebih saham emiten atau perusahaan publik. 2) Nama direktur dan komisaris yang memiliki saham emiten atau perusahaan publik atas saham perusahaan terbuka baik langsung maupun tidak langsung. 3) Pihak yang memiliki saham baik langsung maupun tidak langsung paling sedikit $5 \%$ saham emiten atau perusahaan publik.

Menurut Fleming et al. (2005) variasi struktur kepemilikan mampu mengurangi biaya keagenan pada perusahaan. Perusahaan yang terkonsentrasi dapat mengontrol biaya keagenan, karena mampu mengawasi perilaku manajemen.

Kepemilikan manajerial merupakan proporsi saham biasa yang dimiliki oleh para manajemen. Adanya kepemilikan saham oleh manajerial dapat digunakan untuk mengurangi agency cost yang timbul, karena dengan memiliki saham perusahaan diharapkan manajer akan merasakan langsung manfaat dari setiap keputusan yang diambilnya. Penelitian sebelumnya mengenai pengaruh kepemilikan manajerial pada kinerja keuangan yang dilakukan oleh Hermalin \& S. (1991) serta Lestari \& Juliarto (2017) menyatakan bahwa kepemilikan manajerial berpengaruh positif pada kinerja keuangan. Hal ini menunjukkan 
bahwa kepemilikan manajerial akan mempengaruhi kinerja keuangan perusahaan, disaat manajerial mempunyai kontribusi saham atas perusahaan maka mereka akan bekerja secara bersungguh-sungguh untuk mencapai hasil yang maksimal. Sedangkan penelitian yang dilakukan oleh Wiranata \& Nugrahanti (2013) menyatakan bahwa kepemilikan manajerial tidak berpengaruh pada kinerja keuangan perusahaan.

Kepemilikan institusional adalah kepemilikan saham perusahaan yang dimiliki oleh institusi atau lembaga yang bertugas sebagai orang yang memonitor perusahaan. Semakin tinggi kepemilikan institusional maka dapat mngurangi perilaku opportunistic manajer yang nantinya dapat mengurangi agency cost yang diharapkan akan meningkatkan kinerja keuangan perusahaan. Penelitian Widyati (2013), Haque et al. (2012), Rachman (2014) dan Rimardhani et al. (2016) menyatakan bahwa kepemilikan institusional berpengaruh positif pada kinerja keuangan perusahaan. Sedangkan penelitian yang dilakukan oleh Chiang \& Huang (2012), Karmilayani \& Damayanthi (2016) serta Damayanti \& Suartana (2014) menyatakan bahwa kepemilikan institusional tidak berpengaruh pada kinerja keuangan perusahaan.

Menurut Elkington (1997), jika suatu perusahaan ingin bertahan (going concern) maka harus memperhatikan 3P yaitu profit sebagai keuntungan, people dimana perusahaan harus memperhatikan kesejahteraan masyarakat dan planet merupakan kontribusi perusahaan terhadap lingkungan. Kelangsungan hidup suatu perusahaan tidak hanya dilihat melalui peningkatan kinerja keuangan perusahaan, tetapi juga dari aspek tanggung jawab perusahaan terhadap lingkungan sekitar 
Luh Gede Dian Hermayanti dan I Made Sukartha. Pengaruh ...

tempat perusahaan menjalankan aktivitas perusahaan. Menurut Bowen (1943) keberhasilan suatu perusahaan ditentukan oleh kontribusinya terhadap kesejahteraan umum, bukan hanya untuk kesejahteraan perusahaan itu sendiri. Salah satu cara yang dapat dilakukan oleh perusahaan adalah dengan melaksanakan Corporate Social Responsibility (CSR). Corporate social responsibility (CSR) dipilih dalam penelitian ini karena CSR merupakan salah satu aspek yang dapat mempengaruhi kinerja keuangan perusahaan serta dapat melihat tanggung jawab perusahaan terhadap lingkungan sekitar tempat perusahaan beroperasi. Alasan lainnya karena adanya ketidakkonsistenan hasil penelitian mengenai pengaruh corporate social responsibility (CSR) pada kinerja keuangan perusahaan.

Merujuk pada teori legitimasi yang menegaskan untuk memperoleh kepercayaan dari masyarakat atas kegiatan yang dilakukan, maka perusahaan harus menjalin kegiatannya sesuai dengan norma dan nilai yang berlaku di lingkungan sekitar. Perusahaan akan terus berupaya untuk memastikan bahwa mereka beroperasi dalam norma dan nilai-nilai yang ada dalam masyarakat atau lingkungan tempat perusahaan beroperasi. Praktik CSR dianggap penting oleh perusahaan karena selain berorientasi terhadap laba, perusahaan juga harus bertanggung jawab terhadap masalah sosial yang mereka timbulkan sebagai akibat dari aktivitas operasional yang dilakukan perusahaan terhadap lingkungan Dewi \& Widagdo (2012). Oleh karena itu perusahaan dapat memperoleh legitimasi dengan memperlihatkan tanggung jawab sosial melalui pengungkapan CSR dalam media termasuk dalam laporan tahunan Putra \& Wirakusuma (2015). 
Pengungkapan CSR dalam laporan keuangan masih belum ada pedoman pasti, namun pelaporan CSR perusahaan dapat mengacu pada Pernyataan Standar Akuntansi Keuangan (PSAK) No.1 tentang penyajian dan pengungkapan laporan keuangan, khususnya paragraf kesembilan. Pada PSAK tidak secara tegas mengharuskan perusahaan untuk melaporkan tanggung jawab sosial perusahaan. Akibatnya akan berdampak pada tidak seriusnya perusahaan dalam mengungkapkan tanggung jawab sosial perusahaan serta akan berakibat pada berbedanya tingkat pengungkapan tanggung jawab sosial perusahaan. Jika perusahaan ingin mendapatkan respon yang positif dari pemegang saham dan masyarakat, maka perusahaan akan mengungkapkan tangung jawab sosial yang telah dilaksanakan oleh perusahaan guna untuk meningkatkan kinerja perusahaan. Ada beberapa manfaat pengungkapan CSR, yaitu perusahaan dapat tumbuh berkelanjutan dan mendapatkan citra yang positif dari masyarakat luas, kemudahan akan akses terhadap modal, perusahaan dapat mempertahankan sumber daya manusia yang unggul dan berkualitas, serta pengambilan keputusan perusahaan terhadap hal-hal yang bersifat kritis meningkat dan perusahaan dapat mengelola manajemen risiko dengan lebih mudah.

Berikut ini beberapa penelitian terdahulu mengenai pengaruh CSR terhadap kinerja keuangan perusahaan. Diantaranya penelitian yang dilakukan oleh Dahlia \& Siregar (2008) menyatakan bahwa CSR berpengaruh positif pada kinerja perusahaan. Penelitian ini sejalan dengan penelitian yang dilakukan oleh Ramdhaningsih \& Utama (2013), dimana didapatkan hasil bahwa pengungkapan CSR berpengaruh positif pada kinerja keuangan perusahaan. 
Luh Gede Dian Hermayanti dan I Made Sukartha. Pengaruh ...

Dari beberapa sektor yang terdapat di Bursa Efek Indonesia penelitian ini dilakukan pada perusahaan pertambangan yang terdaftar di Bursa Efek Indonesia periode 2012-2016. Perusahaan pertambangan dipilih dalam penelitian ini karena memiliki peran penting untuk menyediakan sumber energi yang diperlukan bagi pertumbuhan ekonomi. Perusahaan pertambangan juga dapat membuka lapangan pekerjaan sehingga dapat mengurangi angka pengangguran di suatu Negara, dengan demikian akan dibutuhkan dana yang besar untuk memenuhi hal tersebut maka perusahaan akan membutuhkan dana dari investor. Sektor pertambangan memiliki kontribusi besar terhadap berbagai aspek mulai dari penanaman modal asing (PMA), penanaman modal dalam negeri (PMDN), kegiatan ekspor, penerimaan devisa, pendapatan negara, dan produk domestik bruto. Alasan lain adalah karena perusahaan pertambangan memiliki kontribusi yang cukup besar terhadap masalah-masalah polusi, limbah, keamanan produk dan tenaga kerja (Putra \& Wirakusuma, 2015). Dalam aktivitas operasi perusahaan pasti akan menghasilkan limbah dan hal ini akan mengakibatkan pencemaran lingkungan. Dalam proses produksinya perusahaaan pertambangan juga mengeksploitasi kekayaan alam di tempat perusahaan beroperasi, sehingga sudah menjadi kewajiban bagi perusahaan untuk peduli terhadap lingkungan sekitar tempat perusahaan beroperasi. Terdapat beberapa kasus perusahaan pertambangan yang mengalami kegagalan dalam melaksanakan program CSR antara lain kasus PT Newmont Minahasa Raya, kasus lumpur panas Sidoarjo, kasus PT Chevron Pacific, kasus PetroChina, kasus ConocoPhilips, kasus Niko Resources, dan konflik antara PT Freeport Indonesia dengan rakyat Papua. 
Manajemen adalah struktur atau hierarki di dalam perusahaan yang telah diberikan wewenang oleh stakeholder untuk mengatur dan mengelola perusahaan sesuai dengan visi dan misi yang telah ditetapkan oleh perusahaan. Menurut Jensen \& Meckling (1976), manajemen merupakan pihak yang dikontrak oleh pihak principal untuk menjalankan perusahaan sesuai dengan kepentingan pihak principal. Oleh karena itu manajemen diberikan sebagian kekuasaan untuk membuat keputusan bagi kepentingan principal. Untuk itu, manajemen mempunyai tanggung jawab atas semua tindakan yang dilakukan kepada pemegang saham.

Hubungan antara agen dan principal haruslah ada simetri informasi. Artinya semua informasi mengenai perusahaan yang dimiliki agen seharusnya diungkapkan kepada principal. Kenyataannya, agen selalu memiliki informasi yang lebih banyak dibandingkan dengan principal. Menurut Eisenhardt (1989), teori keagenan dilandasi oleh asumsi-asumsi yaitu asumsi tentang sifat manusia, asumsi keorganisasian, dan asumsi informasi. Tiga asumsi sifat manusia, yaitu (1) manusia pada dasarnya mementingkan dirinya sendiri (self interest), (2) manusia memiliki daya pikir terbatas mengenai persepsi masa mendatang (bounded rationality), dan (3) manusia selalu menghindari risiko (risk averse). Asumsi keorganisasian adalah terdapat konflik antara anggota organisasi, efisiensi sebagai kriteria efektivitas, dan terdapat asimetri informasi antara principal dan agen. Asumsi informasi merupakan informasi sebagai komoditas yang dapat diperjualbelikan. 
Luh Gede Dian Hermayanti dan I Made Sukartha. Pengaruh ...

Agen sebagai pihak yang memiliki kualitas dan kuantitas informasi yang lebih baik dari pada principal akan memanfaatkan hal tersebut untuk memenuhi kepentingannya sendiri dengan melakukan tindakan yang dapat merugikan principal. Permasalahan yang timbul antara principal dan agen menimbulkan biaya keagenan. Menurut Jensen \& Meckling (1976) terdapat tiga macam biaya keagenan, yaitu biaya monitoring oleh principal, biaya bonding oleh agen, dan residual loss. Dalam hal ini biaya monitoring dikeluarkan oleh principal untuk mengawasi dan membatasi kegiatan agen yang tidak sesuai dengan kepentingan principal. Berdasarkan teori keagenan, salah satu cara untuk mengurangi biaya keagenan adalah dengan cara kepemilikan saham oleh manajemen.

Kepemilikan saham oleh manajemen adalah kondisi yang menunjukkan bahwa manajemen memiliki saham dalam perusahaan yang secara aktif ikut mengambil keputusan perusahaan. Kepemilikan saham oleh manajemen bertujuan untuk mensejajarkan kedudukan antara manajemen dengan pemegang saham. Menurut Jensen \& Meckling (1976), semakin besar kepemilikan saham oleh manajemen maka akan berkurangnya kecenderungan manajemen untuk menggunakan sumber daya dan mengurangi biaya agensi sebagai akibat dari adanya perbedaan kepentingan, sehingga akan meningkatkan kinerja keuangan perusahaan. Sebab, manajemen yang memiliki keterlibatan dalam perusahaan melalui kepemilikan manajerial akan merasa memiliki perusahaan sehingga segala keputusan yang diambil oleh manajemen akan dilakukan dengan penuh kehatihatian karena segala keputusan yang diambil akan berdampak pula terhadap dirinya. 
Penelitian yang dilakukan oleh Dewi \& Widagdo (2012) serta Waskito (2014) menyatakan bahwa adanya pengaruh positif antara kepemilikan manajerial dan kinerja keuangan perusahaan. Semakin tinggi kepemilikan manajerial dalam suatu perusahaan, maka kinerja keuangan perusahaan akan tinggi. Hasil penelitian tersebut sejalan dengan penelitian yang dilakukan oleh Lestari \& Juliarto (2017) yang menyatakan kepemilikan manajerial berpengaruh positif pada kinerja keuangan yang diukur dengan menggunakan ROA dan ROE.

Berdasarkan penjelasan diatas maka dapat ditarik sebuah hipotesis, yaitu:

$\mathrm{H}_{1}$ : Kepemilikan manajerial berpengaruh positif pada kinerja keuangan.

Institusi adalah sebuah lembaga yang memiliki kepentingan besar terhadap investasi yang telah ditanamkan dalam perusahaan. Institusi dianggap memiliki kesempatan yang lebih besar dalam memonitor dan mengawasi manajemen agar bertindak sesuai dengan tujuan perusahaan. Menurut Jensen \& Meckling (1976), manajemen merupakan pihak yang dikontrak oleh pihak principal untuk menjalankan perusahaan sesuai dengan kepentingan pihak principal. Oleh karena itu manajemen diberikan sebagian kekuasaan untuk membuat keputusan bagi kepentingan principal. Untuk itu, manajemen mempunyai tanggung jawab atas semua tindakan yang dilakukan kepada pemegang saham.

Hubungan antara agen dan principal haruslah ada simetri informasi. Artinya semua informasi mengenai perusahaan yang dimiliki agen seharusnya diungkapkan kepada principal. Menurut Eisenhardt (1989), teori keagenan 
Luh Gede Dian Hermayanti dan I Made Sukartha. Pengaruh ...

dilandasi oleh asumsi-asumsi yaitu asumsi tentang sifat manusia, asumsi keorganisasian, dan asumsi informasi. Tiga asumsi sifat manusia, yaitu (1) manusia pada dasarnya mementingkan dirinya sendiri (self interest), (2) manusia memiliki daya pikir terbatas mengenai persepsi masa mendatang (bounded rationality), dan (3) manusia selalu menghindari risiko (risk averse). Asumsi keorganisasian adalah terdapat konflik antara anggota organisasi, efisiensi sebagai kriteria efektivitas, dan terdapat asimetri informasi antara principal dan agen. Asumsi informasi merupakan informasi sebagai komoditas yang dapat diperjualbelikan.

Kenyataannya, agen selalu memiliki informasi yang lebih banyak dibandingkan dengan principal, sehingga agen akan memanfaatkan hal tersebut untuk memenuhi kepentingannya sendiri dengan melakukan tindakan yang dapat merugikan principal. Masalah yang ditimbulkan antara agen dan principal karena perbedaan kepentingan mengakibatkan adanya biaya keagenan. Menurut Jensen \& Meckling (1976) terdapat tiga macam biaya keagenan, yaitu biaya monitoring oleh principal, biaya bonding oleh agen, dan residual loss. Dalam hal ini biaya monitoring dikeluarkan oleh principal untuk mengawasi dan membatasi kegiatan agen yang tidak sesuai dengan kepentingan principal. Salah satu cara untuk mengurangi biaya pengawasan adalah dengan kepemilikan institusional. Kepemilikan institusional adalah kepemilikan saham perusahaan yang dimiliki oleh institusi atau lembaga seperti perusahaan asuransi, bank, perusahaan investasi, dan kepemilikan institusi lain (Tarjo, 2008). Menurut Jensen (1986) semakin tinggi tingkat kepemilikan institusional maka semakin kuat tingkat 
pengendalian yang dilaksanakan oleh pihak eksternal pada perusahaan sehingga biaya keagenan dapat menurun. Dengan berkurangnya biaya keagenan akan membuat kinerja keuangan perusahaan meningkat.

Kepemilikan institusional mempunyai waktu lebih banyak untuk mengawasi kegiatan operasional perusahaan sehingga memperkecil kemungkinan untuk manajemen melakukan kecurangan. Kepemilikan institusional bertindak sebagai pihak yang mengawasi perusahaan dan manajemen dalam mengelola perusahaan. Kepemilikan institusional merupakan salah satu faktor yang dapat mempengaruhi kinerja perusahaan. Semakin tinggi kepemilikan institusional maka biaya pengawasan yang dikeluarkan akan semakin rendah sehingga kinerja keuangan perusahaan akan semakin tinggi.

Penelitian yang dilakukan oleh Widyati (2013) dan Haque et al., (2012) menyatakan bahwa kepemilikan institusional memiliki pengaruh positif pada kinerja keuangan perusahaan. Hal tersebut terjadi karena semakin besarnya jumlah kepemilikan saham oleh institusi maka akan meminimalisir masalah keagenan sehingga dapat meningkatkan kinerja keuangan perusahaan. Penelitian tersebut sejalan dengan penelitian yang dilakukan oleh Rachman (2014) dan Rimardhani et al. (2016) yang menyatakan bahwa kepemilikan institusional berpengaruh pada kinerja keuangan perusahaan.

Berdasarkan penjelasan diatas maka dapat ditarik sebuah hipotesis, yaitu:

$\mathrm{H}_{2}$ : Kepemilikan institusional berpengaruh positif pada kinerja keuangan. 
Luh Gede Dian Hermayanti dan I Made Sukartha. Pengaruh ...

Teori legitimasi menegaskan untuk memperoleh kepercayaan dari masyarakat atas kegiatan yang dilakukan, maka perusahaan harus menjalin kegiatannya sesuai dengan norma dan nilai yang berlaku di lingkungan sekitar. Salah satu cara yang dapat dilakukan oleh perusahaan adalah dengan melaksanakan Corporate Social Responsibility (CSR). Praktik CSR dianggap penting oleh perusahaan karena selain berorientasi terhadap laba, perusahaan juga harus bertanggung jawab terhadap masalah sosial yang mereka timbulkan sebagai akibat dari aktivitas operasional yang dilakukan perusahaan terhadap lingkungan.

Dengan diterapkannya CSR di dalam perusahaan diharapkan akan berdampak pada citra perusahaan di mata masyarakat sekitar tempat perusahaan beroperasi. Semakin baik perusahaan melakukan CSR, maka akan terbangun citra perusahaan di mata konsumen. Para konsumen akan memiliki pandangan yang baik terhadap perusahaan, karena perusahaan telah memperhatikan kepentingan masyarakat sekitar. Dengan demikian, konsumen tidak akan keberatan untuk membeli produk perusahaan, sehingga hal tersebut dapat meningkatkan kinerja keuangan perusahaan. Perusahaan perlu melakukan CSR karena akan bermanfaat untuk kondisi perusahaan dalam jangka waktu panjang.

Hasil penelitian yang dilakukan oleh Candrayanthi \& Saputra (2013) serta Hackston \& Milne (1996) menunjukkan hasil bahwa pengungkapan CSR berpengaruh positif pada kinerja keuangan perusahaan, ini berarti dengan mengungkapkan CSR kinerja perusahaan yang diukur dengan ROE akan meningkat. Penelitian ini sejalan dengan penelitian yang dilakukan oleh Ramdhaningsih \& Utama (2013) dan Rahayu et al. (2014), dimana didapatkan 
hasil bahwa pengungkapan CSR berpengaruh positif pada kinerja keuangan perusahaan.

Berdasarkan penjelasan diatas maka dapat ditarik sebuah hipotesis, yaitu:

$\mathrm{H}_{3}$ : Pengungkapan Corporate Social Responsibility berpengaruh positif pada kinerja keuangan.

\section{METODE PENELITIAN}

Lokasi penelitian ini dilakukan pada perusahaan pertambangan yang terdaftar di Bursa Efek Indonesia pada tahun 2012-2016 melalui situs www.idx.co.id. Objek pada penelitian ini adalah kinerja keuangan perusahaan pertambangan yang terdaftar di Bursa Efek Indonesia periode 2012-2016.

Kepemilikan manajerial dihitung dengan menggunakan rumus sebagai berikut:

$$
\begin{aligned}
& \text { jumlah saham dewan direksi } \\
& \text { dan dewan komisaris } \\
& \text { Kepemilikan manajerial }=\frac{}{\text { jumlah saham yang beredar }} \times 100 \% \ldots \ldots \ldots \ldots \ldots \ldots . . . .(1)
\end{aligned}
$$

Kepemilikan Institusional dihitung dengan menggunakan rumus sebagai berikut:

Kepemilikan institusional $=\frac{\text { jumlah saham institusi }}{\text { jumlah saham yang beredar }} \times 100 \%$

Item pengungkapan ISO 26000 yang digunakan menjadi pengungkapan kinerja sosial dalam penilitian ini sebagai berikut (Saputro \& Raharja, 2014). 
Indeks Kepatuhan $=\frac{\sum \mathrm{Xn}}{37}$

Keterangan:

$\sum \mathrm{Xn}=$ jumlah pelaksanaan perusahaan sampel pada setiap tema

$37=$ jumlah item pelaksanaan dalam ISO 26000

Rumus yang digunakan dalam rasio ROE adalah (Brigham \& Houston,

2010:149):

$$
\mathrm{ROE}=\frac{\text { laba bersih setelah pajak }}{100 \%}
$$

Keterangan:

(1) Laba bersih setelah pajak yang digunakan dalam penelitian ini adalah laba bersih setelah pajak pada periode $t$.

(2) Total ekuitas yang digunakan dalam penelitian ini adalah total ekuitas pada periode t-1 (sebelumnya).

Populasi dalam penelitian ini adalah perusahaan pertambangan yang terdaftar di Bursa Efek Indonesia pada tahun 2012-2016. Pengumpulan data dalam penelitian ini dilakukan dengan cara mengamati, mencatat dan mempelajari uraian-uraian dari laporan keuangan yang diperoleh dengan mengakses website Bursa Efek Indonesia yaitu www.idx.co.id.

Teknis analisis data yang digunakan dalam penelitian ini adalah analisis regresi linier berganda. Analisis regresi linier berganda merupakan teknis statistik melalui koefisien parameter untuk mengetahui besarnya pengaruh variabel independen terhadap variabel dependen. Pengujian hipotesis secara parsial maupun simultan dilakukan sevelah model regresi yang digunakan bebas dari pelanggaran asumsi klasik. Dalam penelitian ini teknik analisis regresi linier berganda digunakan untuk mengetahui pengaruh variabel independen berupa 
kepemilikan institusional, kepemilikan manajerial dan corporate social responsibility serta pada variabel dependen berupa kinerja keuangan perusahaan. Persamaan regresi tersebut adalah sebagai berikut:

$\mathrm{Y}=\alpha+\beta_{1} \mathrm{X}_{1}+\beta_{2} \mathrm{X}_{2}+\beta_{3} \mathrm{X}_{3}+\varepsilon$

Keterangan:

\begin{tabular}{|c|c|}
\hline Y & $=$ kinerja keuangan \\
\hline$\alpha$ & $=$ konstanta \\
\hline$\beta_{1}, \beta_{2}, \beta_{3}$ & $=$ koefisien regresi untuk setiap variabel independen \\
\hline $\mathrm{X}_{1}$ & $=$ kepemilikan institusional \\
\hline $\mathrm{X}_{2}$ & $=$ kepemilikan manajerial \\
\hline $\mathrm{X}$ & $=$ corporate social responsibility \\
\hline & $=$ error \\
\hline
\end{tabular}

\section{HASIL DAN PEMBAHASAN}

Statistik deskriptif digunakan untuk memberikan informasi mengenai karakteristik penelitian terkait dengan nilai minimun, nilai maksimum, nilai rata-rata, dan standar deviasi dari masing-masing variabel. Berdasarkan pengolahan data SPSS tentang pengujian statistik deskriptif mengenai variabel kinerja keuangan, kepemilikan manajerial, kepemilikan institusional, pengungkapan corporate social responsibility, maka didapatkan hasil analisis yang disajikan dalam Tabel 1.

Tabel 1.

Hasil Statistik Deskriptif

\begin{tabular}{llrrrr}
\hline & $\mathrm{N}$ & Minimum & Maximum & Mean & Std.Deviation \\
\hline $\mathrm{Y}$ & 40 & $-1,17$ & 0,42 & 0,0338 & 0,29629 \\
$\mathrm{X} 1$ & 40 & 0,00 & 0,26 & 0,0595 & 0,07937 \\
$\mathrm{X} 2$ & 40 & 0,04 & 0,93 & 0,4947 & 0,29148 \\
X3 & 40 & 0,24 & 0,62 & 0,4113 & 0,11483 \\
Valid N (listwise)40 & & & & & \\
\hline
\end{tabular}

Sumber: Data diolah, 2019

Berdasarkan tabel 1 dapat dijelaskan bahwa variabel terikat kinerja keuangan memiliki nilai minimum sebesar -1,17 pada Energi Mega Persada Tbk 
Luh Gede Dian Hermayanti dan I Made Sukartha. Pengaruh ...

di periode pengamatan 2016, sedangkan nilai maksimum sebesar 0,42 pada Harum Energy Tbk di periode pengamatan 2012. Kinerja keuangan memiliki mean atau nilai rata-rata sebesar 0,0338 dan standar deviasi sebesar 0,29629.

Variabel bebas kepemilikan manajerial memiliki nilai minimum sebesar 0,00 pada 4 perusahaan selama periode 2012-2016, yaitu Energi Mega Persada Tbk, Harum Energy Tbk, Mitra Investindo Tbk dan Tambang Batubara Bukit Asam (Persero) Tbk. Nilai maksimum sebesar 0,26 pada Atlas Resources Tbk periode 2012. Kepemilikan manajerial memiliki nilai mean sebesar 0,0595 dengan standar deviasi sebesar 0,07937.

Variabel bebas kepemilikan institusional memiliki nilai minimum sebesar 0,04 pada Mitra Investindo Tbk periode 2014-2016, sedangkan nilai maksimum sebesar 0,93 pada Toba Bara Sejahtera Tbk pada periode 2013-2016. kepemilikan institusional memiliki nilai rata-rata sebesar 0,4947 dengan standar deviasi sebesar 0,29148.

Variabel bebas pengungkapan CSR memiliki nilai minimum sebesar 0,24 pada Mitra Investindo Tbk periode 2016 dan Tambang Batubara Bukit Asam (Persero) Tbk pada periode 2012. Nilai maksimum sebesar 0,62 pada Atlas Resources Tbk periode 2012-2013 dan periode 2015-2016 serta pada Tambang Batubara Bukit Asam (Persero) Tbk periode 2016. Pengungkapan CSR memiliki nilai rata-rata sebesar 0,4113 dengan standar deviasi sebesar 0,11483.

Uji F digunakan untuk menguji kelayakan atau validitas dari suatu model regresi. Hasil uji statistik F (uji F) dapat dilihat pada Tabel 4.7 berikut. 
Tabel 2.

Hasil Uji Statistik F (Uji F)

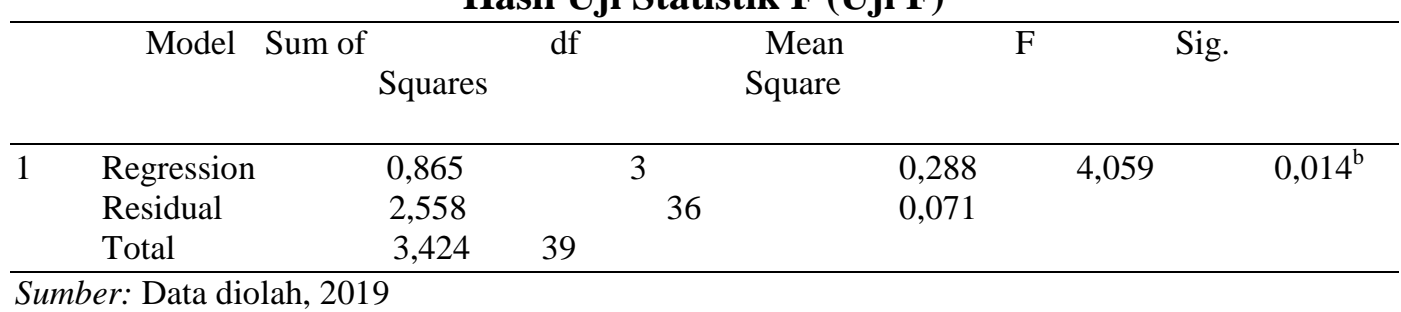

Berdasarkan Tabel 2 hasil pengujian $\mathrm{F}$ menunjukkan angka sebesar 4,059 dengan tingkat signifikansi 0,014 lebih kecil dari $\alpha=0,05$. Berdasarkan hasil tersebut dapat disimpulkan bahwa model ini layak digunakan dalam penelitian.

Koefisien determinasi $\left(\mathrm{R}^{2}\right)$ dilakukan untuk mengukur seberapa jauh kemampuan variansi variabel independen dapat menerangkan variansi variabel dependen. Koefisien determinasi dalam penelitian ini dilihat dari adjusted $R$ square. Hasil koefisien determinasi dalam penelitian disajikan dalam Tabel 3 berikut.

Tabel 3.

Hasil Koefisien Determinasi $\left(\mathbf{R}^{2}\right)$

\begin{tabular}{ccccc}
\hline Model & R & R Square & $\begin{array}{c}\text { Adjusted R } \\
\text { Square }\end{array}$ & $\begin{array}{c}\text { Std. Error of the } \\
\text { Estimate }\end{array}$ \\
\hline 1 & $0,485^{\text {a }}$ & 0,253 & 0,170 & 0,26350 \\
\hline
\end{tabular}

Sumber: Data diolah, 2019

Berdasarkan Tabel 3, dapat disimpulkan bahwa nilai adjusted $R$ square sebesar 0,170 memiliki arti bahwa 17 persen variasi dari variabel dependen, yaitu kinerja keuangan (Y) dapat dijelaskan oleh variasi dari variabel independen yaitu kepemilikan manajerial $\left(\mathrm{X}_{1}\right)$, kepemilikan institusional $\left(\mathrm{X}_{2}\right)$, dan pengungkapan CSR $\left(\mathrm{X}_{3}\right)$, sedangkan sisanya 83 persen dijelaskan oleh faktor-faktor lain yang tidak dimasukkan ke dalam model regresi. 
Model analisis yang digunakan dalam penelitian ini adalah analisis regresi linier berganda. Analisis regresi linier berganda merupakan teknis statistik melalui koefisien parameter untuk mengetahui besarnya pengaruh variabel independen pada variabel dependen. Dalam penelitian ini teknik analisis regresi linier berganda digunakan untuk mengetahui pengaruh variabel independen berupa kepemilikan manajerial $\left(\mathrm{X}_{1}\right)$, kepemilikan institusional $\left(\mathrm{X}_{2}\right)$, dan pengungkapan CSR $\left(\mathrm{X}_{3}\right)$ pada variabel dependen berupa kinerja keuangan (Y) perusahaan pertambangan yang terdaftar di Bursa Efek Indonesia periode 20122016. Hasil analisis regresi linier berganda dalam penelitian ini disajikan dalam Tabel 4 berikut.

Tabel 4.

Hasil Analisis Regresi Linier Berganda

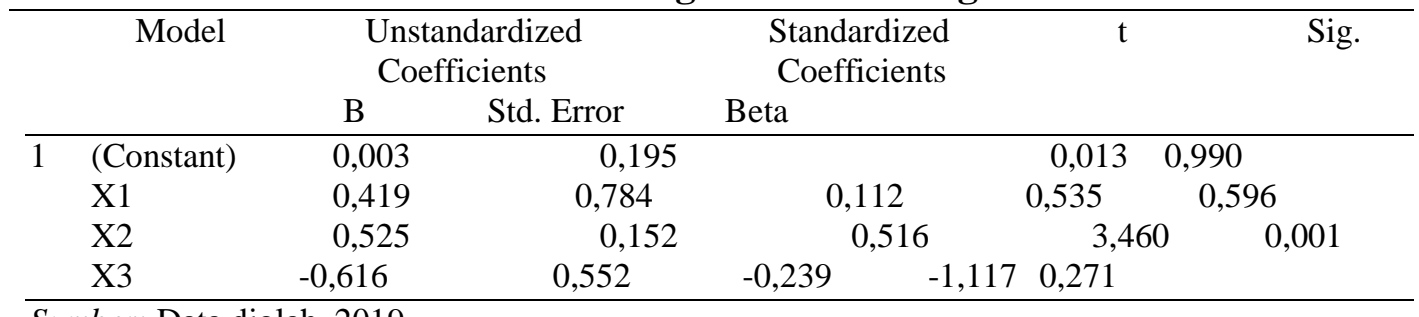

Sumber: Data diolah, 2019

Berdasarkan hasil analisis pada Tabel 4 maka persamaan regresi yang digunakan dalam penelitian ini dapat ditulis sebagai berikut.

$$
\mathrm{Y}=0,003+0,419 \mathrm{X}_{1}+0,525 \mathrm{X}_{2}-0,616 \mathrm{X}_{3}+\varepsilon
$$

Nilai konstanta 0,003 menunjukkan bahwa apabila kepemilikan manajerial $\left(\mathrm{X}_{1}\right)$, kepemilikan institusional $\left(\mathrm{X}_{2}\right)$, dan pengungkapan CSR $\left(\mathrm{X}_{3}\right)$ sama dengan nol, maka nilai kinerja keuangan (Y) tidak ada. Nilai Koefisien $\beta_{1}=0,419$ menunjukkan bahwa jika nilai kepemilikan manajerial $\left(\mathrm{X}_{1}\right)$ bertambah 1 satuan, 
maka nilai kinerja keuangan (Y) tidak berubah dengan asumsi variabel lainnya konstan. Nilai Koefisien $\beta_{2}=0,525$ menunjukkan bahwa jika nilai kepemilikan institusional $\left(\mathrm{X}_{2}\right)$ bertambah 1 satuan, maka nilai kinerja keuangan (Y) akan berubah sebesar 0,525 satuan dengan asumsi variabel lainnya konstan. Nilai Koefisien $\beta_{3}=-0,616$ menunjukkan bahwa jika nilai pengungkapan $\operatorname{CSR}\left(\mathrm{X}_{3}\right)$ bertambah 1 satuan, maka nilai kinerja keuangan (Y) tidak berubah dengan asumsi variabel lainnya konstan.

Berdasarkan uji statistik $\mathrm{t}$ pada Tabel 4 diketahui bahwa variabel kepemilikan manajerial $\left(\mathrm{X}_{1}\right)$ menunjukkan $\mathrm{t}_{\text {hitung }}=0,535$ dengan tingkat signifikansi sebesar 0,596 . Nilai signifikansi lebih besar dari $\alpha=0,05$ atau nilai 0,596>0,05 maka hipotesis pertama ditolak, yang menunjukkan variabel kepemilikan manajerial tidak berpengaruh pada kinerja keuangan.

Berdasarkan uji statistik t pada Tabel 4 diketahui bahwa variabel kepemilikan institusional $\left(\mathrm{X}_{2}\right)$ menunjukkan $\mathrm{t}_{\text {hitung }}=3,460$ dengan tingkat signifikansi sebesar 0,001 . Nilai signifikansi lebih besar dari $\alpha=0,05$ atau nilai $0,001<0,05$ maka hipotesis kedua diterima, yang menunjukkan variabel kepemilikan institusional berpengaruh positif pada kinerja keuangan.

Berdasarkan uji statistik t pada Tabel 4 diketahui bahwa variabel pengungkapan CSR $\left(\mathrm{X}_{3}\right)$ menunjukkan $\mathrm{t}_{\text {hitung }}=-1,117$ dengan tingkat signifikansi sebesar 0,271 . Nilai signifikansi lebih besar dari $\alpha=0,05$ atau nilai $0,271>0,05$ maka hipotesis ketiga ditolak, yang menunjukkan variabel pengungkapan CSR tidak berpengaruh pada kinerja keuangan. 
Luh Gede Dian Hermayanti dan I Made Sukartha. Pengaruh ...

Hipotesis pertama $\left(\mathrm{H}_{1}\right)$ menyatakan kepemilikan manajerial tidak berpengaruh pada kinerja keuangan. Hasil analisis pada Tabel 4 menyatakan nilai koefisien sebesar 0,419 dengan tingkat signifikan sebesar 0,596 yang lebih tinggi dari tingkat taraf nyata penelitian sebesar 0,05. Hal ini menunjukkan bahwa kepemilikan manajerial perusahaan pertambangan yang terdaftar di Bursa Efek Indonesia periode 2012-2016 tidak berpengaruh pada kinerja keuangan. Dengan demikian hipotesis pertama pada penelitian ini ditolak.

Penelitian ini bertentangan dengan teori keagenan yang menyatakan bahwa semakin tinggi tingkat kepemilikan manajerial pada perusahaan, maka akan berkurangnya kecenderungan manajemen untuk menggunakan sumber daya dan mengurangi biaya agensi sebagai akibat dari adanya perbedaan kepentingan, sehingga akan meningkatkan kinerja keuangan perusahaan. Secara deskriptif kepemilikan manajerial memiliki nilai rata-rata sebesar 5,9 persen yang artinya kepemilikan manajerial dalam suatu perusahaan masih rendah sehingga kepemilikan manajerial tidak direspon positif oleh pihak investor sebagai sinyal positif untuk meningkatkan kinerja keuangan. Rendahnya saham yang dimiliki oleh pihak manajemen mengakibatkan pihak manajemen belum merasa ikut memiliki perusahaan karena tidak semua keuntungan perusahaan dapat dirasakan oleh pihak manajemen sehingga dapat menyebabkan pihak manajemen kurang termotivasi dalam melaksanakan tanggung jawabnya untuk menjalankan kegiatan perusahaan.

Dilihat dari hasil statistik deskriptif nilai rata-rata kepemilikan manajerial sebesar 0,0595 atau senilai 5,95\%. Hal tersebut menunjukkan bahwa 
nilai rata-rata kepemilikan manajerial selama periode 2012-2016 lebih rendah dari 0,5 atau senilai 50\%. Rendahnya nilai rata-rata kepemilikan manajerial mengindikasikan bahwa kepemilikan manajerial tidak berpengaruh pada kinerja keuangan perusahaan.

Penelitian ini sesuai dengan penelitian yang dilakukan oleh Rachman (2014) dan Epi (2017) yang menyatakan bahwa kepemilikan manajerial tidak berpengaruh pada kinerja keuangan. Hal ini berarti ada atau tidaknya kepemilikan manajerial dalam suatu perusahaan tidak dapat mempengaruhi kinerja keuangan perusahaan.

Hipotesis kedua $\left(\mathrm{H}_{2}\right)$ menyatakan kepemilikan institusional berpengaruh positif pada kinerja keuangan. Hasil analisis pada Tabel 4 menyatakan nilai koefisien sebesar 0,525 dengan tingkat signifikan sebesar 0,001 yang lebih rendah dari tingkat taraf nyata penelitian sebesar 0,05 . Hal ini menunjukkan bahwa kepemilikan institusional perusahaan pertambangan yang terdaftar di Bursa Efek Indonesia periode 2012-2016 berpengaruh positif pada kinerja keuangan. Dengan demikian hipotesis kedua pada penelitian ini diterima.

Penelitian ini mendukung teori keagenan yang menyatakan bahwa kepemilikan institusional merupakan salah satu faktor yang dapat mempengaruhi kinerja keuangan perusahaan. Adanya kepemilikan oleh investor institusional dapat mendorong peningkatan pengawasan yang lebih optimal terhadap kinerja manajemen karena kepemilikan saham mewakili kekuasaan yang dapat digunakan untuk mendukung atau memperburuk kinerja manajemen. Pengawasan yang tinggi akan meminimalisir adanya penyelewengan yang dilakukan oleh pihak 
Luh Gede Dian Hermayanti dan I Made Sukartha. Pengaruh ...

manajemen yang dapat menurunkan kinerja keuangan perusahaan. Semakin tinggi tingkat kepemilikan institusional maka semakin kuat tingkat pengendalian yang dilaksanakan oleh pihak eksternal pada perusahaan sehingga biaya keagenan yang timbul dapat menurun. Dengan berkurangnya biaya keagenan akan membuat kinerja keuangan perusahaan meningkat.

Penelitian ini sejalan dengan penelitian yang dilakukan oleh Rachman (2014) serta Lestari \& Juliarto (2017) yang menyatakan bahwa kepemilikan institusional berpengaruh positif pada kinerja keuangan perusahaan. Kepemilikan saham yang tinggi oleh pihak institusi akan meningkatkan pengawasan terhadap kinerja manajemen dalam menjalankan kegiatan perusahaan. Peningkatan pengawasan pada manajemen membuat manajemen berusaha untuk meningkatkan kinerjanya sehingga sesuai dengan visi, misi, dan tujuan perusahaan.

Hipotesis ketiga $\left(\mathrm{H}_{3}\right)$ menyatakan pengungkapan CSR tidak berpengaruh pada kinerja keuangan. Hasil analisis pada Tabel 4 menyatakan nilai koefisien sebesar -0,616 dengan tingkat signifikan sebesar 0,271 yang lebih tinggi dari tingkat taraf nyata penelitian sebesar 0,05 . Hal ini menunjukkan bahwa pengungkapan CSR perusahaan pertambangan yang terdaftar di Bursa Efek Indonesia periode 2012-2016 tidak berpengaruh pada kinerja keuangan. Dengan demikian hipotesis ketiga pada penelitian ini dapat ditolak.

Hasil penelitian ini tidak sesuai dengan teori legitimasi yang menyatakan bahwa untuk memperoleh kepercayaan dari masyarakat perusahaan harus menjalankan kegiatan operasi perusahaan sesuai dengan nilai dan norma yang berlaku dalam masyarakat sekitar tempat perusahaan beroperasi. Salah satu cara 
yang dapat dilakukan oleh perusahaan adalah dengan cara menerapkan praktik corporate social responsibility (CSR). Setelah melaksanakan praktik CSR, perusahaan akan mengungkapkannya dalam laporan tahunan perusahaan. Namun kenyataannya, pengungkapan CSR dalam laporan tahunan tidak memberikan pengaruh terhadap kinerja keuangan perusahaan. Pengungkapan praktik CSR dalam laporan tahunan digunakan untuk menutupi keburukan kinerja keuangan perusahaan. Dalam pengungkapan CSR, perusahaan akan menyajikan laporan yang baik demi memperoleh citra yang baik bagi pihak investor maupun konsumen.

Dilihat dari hasil statistik deskriptif nilai rata-rata pengungkapan CSR sebesar 0,4113 atau senilai $41,13 \%$. Hal tersebut menunjukkan bahwa nilai ratarata pengungkapan CSR selama periode 2012-2016 lebih rendah dari 0,5 atau senilai 50\%. Rendahnya nilai pengungkapan CSR mengindikasikan bahwa pengungkapan CSR tidak berpengaruh pada kinerja keuangan perusahaan.

Penelitian Stacia \& Juniarti (2015) dan Yaparto et al. (2013) sejalan dengan penelitian ini, bahwa pengungkapan CSR tidak berpengaruh pada kinerja keuangan. Hal ini menunjukkan bahwa naik atau turunnya kinerja keuangan tidak dipengaruhi oleh pengungkapan CSR karena investor tidak terlalu memperhatikan kegiatan CSR yang telah dilakukan oleh perusahaan, tetapi lebih terfokus pada kinerja perusahaan. 
Luh Gede Dian Hermayanti dan I Made Sukartha. Pengaruh ...

\section{SIMPULAN}

Kepemilikan manajerial tidak berpengaruh pada kinerja keuangan perusahaan pertambangan yang terdaftar di Bursa Efek Indonesia periode 2012-2016. Kepemilikan institusional berpengaruh positif pada kinerja keuangan perusahaan pertambangan yang terdaftar di Bursa Efek Indonesia periode 2012-2016. Pengungkapan CSR tidak berpengaruh pada kinerja keuangan perusahaan pertambangan yang terdaftar di Bursa Efek Indonesis periode 2012-2016.

Diharapkan dalam melaksanakan pengawasan terhadap manajemen diperlukan strategi yang baik agar tidak menimbulkan biaya keagenan yang nantinya akan menurunkan kinerja keuangan perusahaan. Terdapat beberapa cara yang dapat dilakukan oleh perusahaan untuk mengurangi biaya keagenan yaitu meningkatkan kepemilikan manajerial, mempertahankan atau meningkatkan kembali kepemilikan institusional, memperhatikan program-program dalam melaksanakan praktik CSR agar dapat memberikan manfaat bagi kelangsungan hidup masyarakat dan lingkungan sekitar.

Diharapkan pada penelitian selanjutnya menggunakan lebih banyak sampel perusahaan yang terdaftar di Bursa Efek Indonesia. Penelitian selanjutnya diharapkan pula menambahkan variabel independen lain agar hasil penelitian yang diperoleh menjadi lebih beragam. 


\section{REFERENSI}

Bowen, H. R. (1943). The Interpretation of Voting in the Allocation of Economic Resources. The Quarterly Journal of Economics, 58(1), 27-48. https://doi.org/10.2307/1885754

Brigham, \& Houston. (2010). Dasar-dasar Manajemen Keuangan Buku 1 (11th ed.). Jakarta: Salemba Empat.

Candrayanthi, A. A. A., \& Saputra, I. D. G. D. (2013). Pengaruh Pengungkapan Corporate Social Responsibility Terhadap Kinerja Perusahaan (Studi Empiris Pada Perusahaan Pertambangan Di Bursa Efek Indonesia). E-Jurnal Akuntansi Universitas Udayana, 4(1), 141-158. Retrieved from https://ojs.unud.ac.id/index.php/Akuntansi/article/view/5899

Chiang, Y., \& Huang, H. (2012). An Empirical Study of Equity Agency Cost and Internationalization: The Effect Of Revised Accounting Standards In Taiwan. The International Journal of Business and Finance Research, 6(2), 101-111.

Dahlia, L., \& Siregar, S. V. (2008). Pengaruh Corporate Social Responsibility terhadap Kinerja Perusahaan (Studi Empiris pada Perusahaan yang Tercatat di Bursa Efek Indonesia pada tahun 2005-2006. Simposium Nasional Akuntansi XI Pontianak, 11.

Damayanti, N. P. W. P., \& Suartana, I. W. (2014). Pengaruh Kepemilikan Manajerial Dan Kepemilikan Institusional Pada Nilai Perusahaan. E-Jurnal Akuntansi Universitas Udayana, 9(3), 575-590.

Dewi, R. K., \& Widagdo, B. (2012). Pengaruh Corporate Social Responsibility dan Good Corporate Governance Terhadap Kinerja Perusahaan. Jurnal Manajemen Bisnis, 2(1), 81-98. https://doi.org/10.22219/jmbumm.Vol2.No1.\%25p

Eisenhardt, K. M. (1989). Agency Theory: An Assessment and Review. Academy of Management Review, 14(1), 57-74. https://doi.org/10.5465/amr.1989.4279003

Elkington, J. (1997). Enter the Triple Bottom Line. Capstone Publishing Ltd, London, 10(1), 1-16.

Epi, Y. (2017). Pengaruh Ukuran Perusahaan, Struktur Kepemilikan Manajerial dan Manajemen Laba Terhadap Kinerja Perusahaan Property dan Real Estate yang Terdaftar Pada Bursa Efek Indonesia. Owner Riset Dan Jurnal Akuntansi, 1(1). 
Fleming, G., Heaney, R., \& McCosker, R. (2005). Agency Cost and Ownership Structure in Australia. Pacific-Basin Finance Journal, 13(1), 29-52. https://doi.org/10.1016/j.pacfin.2004.04.001

Hackston, D., \& Milne, M. J. (1996). Some determinants of social and environmental disclosures in New Zealand companies. Accounting, Auditing \& Accountability Journal, 9(1), 77-108. https://doi.org/10.1108/09513579610109987

Haque, M., Karim, A. N. M., Muqtadir, A., \& Anam, S. (2012). Dimensions of Job Satisfaction of Library Professionals: A Qualitative Exploration. International Journal of Bussines and Social Research, 2(5), 46-62.

Hermalin, B. E., \& S., M. (1991). The Effect of Board Composition and Direct Incentives on Firm Performance. Journal of Financial Management, 20(4), 101-112. https://doi.org/10.2307/3665716

Jensen, M. ., \& Meckling, W. . (1976). Theory of the Firm: Managerial Behavior, Agendy Costs and Ownership Structure. Journal of Financial Economics 3, 3, 305-360. https://doi.org/10.1016/0304-405X(76)90026-X

Jensen, M. C. (1986). Agency Costs of Free Cash Flow, Corporate Finance, and Takeovers. AEA PApers and Proceedings, 76(2), 323-329. Retrieved from https://www.jstor.org/stable/1818789

Karmilayani, N. K., \& Damayanthi, I. G. A. E. (2016). Corporate Social Responsibility Sebagai Pemoderasi Pengaruh Kepemilikan Manajerial dan Kepemilikan Institusional Pada Kinerja Perusahaan. E-Jurnal Akuntansi Universitas Udayana, 14(3), 2220-2250.

Lestari, N. P., \& Juliarto, A. (2017). Pengaruh Dimensi Struktur Kepemilikan Terhadap Kinerja Perusahaan Manufaktur. Diponegoro Journal of Accounting, 6(3), 1-10.

Putra, I. G. A. N. B. D., \& Wirakusuma, M. G. (2015). Pengaruh Pengungkapan Corporate Social Responsibility Pada Nilai Perusahaan Dengan Profitabilitas Sebagai Variabel Pemoderasi. E-Jurnal Akuntansi Universitas Udayana, 13(2), 461-475.

Rachman, R. A. (2014). Pengaruh Kepemilikan Manajerial dan Kepemilikan Institusional Terhadap Kinerja Keuangan Pada Perusahaan manufaktur Yang Terdaftar di Bursa Efek Indonesia. Artikel Ilmiah Sekolah Tinggi Ilmu Ekonomi Perbanas Surabaya.

Rahayu, W., Darminto, \& Topowijono. (2014). Pengaruh Pengungkapan Corporate Social Responsibility (CSR) Terhadap Profitabilitas Perusahaan (Studi Pada Perusahaan Sektor Pertambangan Periode 2012-2013 yang 
Terdaftar di Bursa Efek Indonesia). Jurnal Administrasi Bisnis (JAB), 17(2), $1-8$.

Ramdhaningsih, A., \& Utama, I. M. K. (2013). Pengaruh Indikator Good Corporate Governance dan Profitablitas Pada Pengungkapan Corporate Social Responsibility. E-Jurnal Akuntansi Universitas Udayana, 3(3), 65-82.

Rimardhani, H., Hidayat, R. R., \& Dwiatmanto. (2016). Pengaruh Good Corporate Governance Terhadap Profitabilitas Perusahaan (Studi Pada Perushaan BUMN Yang Terdaftar di BEI Tahun 2012-2014). Jurnal Administrasi Bisnis (JAB), 31(1), 167-175.

Saputro, T. D., \& Raharja. (2014). Pengaruh Profitabilitas, Umur Perusahaan, Tipe Perusahaan, dan Kepemilikan Manajemen Terhadap Pengungkapan Sosial Berdasar ISO 26000 (Studi Empiris pada Perusahaan Pertambangan dan Keuangan yang Terdaftar di BEI Tahun 2011-2012). Diponegoro Journal of Accounting, 3(1), 1-9.

Stacia, E., \& Juniarti. (2015). Pengaruh Pengungkapan Corporate Social Responsibility terhadap Nilai Perusahaan di Sektor Pertambangan. Business Accounting Review, 3(2), 81-90.

Tarjo. (2008). Pengaruh Konsentrasi Kepemilikan Institusional Dan Leverage Terhadap Manjemen Laba, Nilai Pemegang Saham Serta Cost of Equity Capital. Simposium Nasional Akuntansi XI Pontianak.

Wahidahwati. (2002). Pengaruh Kepemilikan Manajerial dan Kepemilikan Institusional Pada Kebijakan Hutang Perusahaan: Sebuah Perspektive Theory Agency. The Indonesian Journal of Accounting Research, 5(1).

Waskito, T. (2014). Pengaruh Struktur Kepemilikan Manajerial, Kepemilikan Insttusional, dan Ukuran Perusahaan Terhdap Kinerja Keuangan (Ditinjau Dari Perusahaan Manufaktur Yang Terdaftar Di Bursa Efek Indonesia Tahun 2008 Sampai Dengan Tahun 2011). Universitas Muhammadiyah Surakarta.

Widyati, M. F. (2013). Pengaruh Dewan Direksi, Komisaris Independen, Komite Audit, Kepemilikan Manajerial Dan Kepemilikan Institusional Terhadap Kinerja Keuangan. Jurnal Ilmu Manajemen, 1(1).

Wiranata, Y. A., \& Nugrahanti, Y. W. (2013). Pengaruh Struktur Kepemilikan Terhadap Profitabilitas Perusahaan Manufaktur di Indonesia. Jurnal Akuntansi Dan Keuangan, 15(1), 15-26. https://doi.org/10.9744/jak.15.1.1526

Yaparto, M., K., D. F., \& Eriandani, R. (2013). Pengaruh Corporate Social Responsibility Terhadap Kinerja Keuangan Pada Sektor Manufaktur Yang 
Luh Gede Dian Hermayanti dan I Made Sukartha. Pengaruh ...

Terdaftar Di Bursa Efek Indonesia Pada Periode 2010-2011. Jurnal Ilmiah Mahasiswa Universitas Surabaya, 2(1), 1-19. 